\title{
Evaluation of some properties of fermented milk beverages that affect the demineralization of dental enamel
}

\section{Carolina Simonetti Lodi(a) Kikue Takebayashi Sassaki(b) Fabian Calixto Fraiz ${ }^{(c)}$ Alberto Carlos Botazzo Delbem ${ }^{(d)}$ Cleide Cristina Rodrigues Martinhon ${ }^{(d)}$}

(a) $\mathrm{MSc}_{\text {; }}$ (d)PhD - Department of Pediatric and Social Dentistry, Faculdade de Odontologia de Araçatuba, Unesp - Univ Estadual Paulista, Araçatuba, SP, Brazil.

(b) PhD, Department of Basic Sciences, Faculdade de Odontologia de Araçatuba, Unesp - Univ Estadual Paulista, Araçatuba, SP, Brazil.

(c) PhD, Department of Stomatology, Federal University of Paraná, Curitiba, PR, Brazil.

\section{Corresponding author:}

Cleide Cristina Rodrigues Martinhon Departmento de Odontologia Infantil e Social Faculdade de Odontologia de Araçatuba, Universidade Estadual Paulista (UNESP) Rua José Bonifácio, 1193

CEP: 16015-050

Araçatuba - São Paulo - Brazil

E-mail: cleidecristina@foa.unesp.br

Received for publication on Jan 19, 2009 Accepted for publication on Oct 22, 2009

\begin{abstract}
The aim of this in vitro study was to evaluate the erosive capacity of fermented milk beverages, as well as some of their properties that affect the demineralization of dental enamel $(\mathrm{pH}$, buffering capacity, fluoride, calcium and phosphorus contents). Three different batches of 6 commercial brands of fermented milk beverages were analyzed. $\mathrm{pH}$ evaluation was accomplished using a potentiometer. The buffering capacity was measured by adding $1 \mathrm{~mol} \mathrm{~L}^{-1} \mathrm{NaOH}$. Fluoride concentration was assessed by an ion specific electrode after hexamethyldisiloxane-facilitated diffusion, and calcium and phosphorus concentrations were assessed by a colorimetric test using a spectrophotometer. Sixty specimens of bovine enamel were randomly assigned to 6 groups $(n=10)$. They were exposed to 4 cycles of demineralization in the fermented milk and remineralization in artificial saliva. Enamel mineral loss was determined by surface microhardness (\%SMHC) and profilometric tests. The samples' $\mathrm{pH}$ ranged from 3.51 to 3.87 ; the buffering capacity ranged from 470.8 to $804.2 \mu \mathrm{l}$ of $1 \mathrm{~mol} \mathrm{~L}^{-1} \mathrm{NaOH}$; the fluoride concentration ranged from 0.027 to $0.958 \mu \mathrm{gF} / \mathrm{g}$; the calcium concentration ranged from 0.4788 to $0.8175 \mathrm{mgCa} / \mathrm{g}$; and the phosphorus concentration ranged from 0.2662 to $0.5043 \mathrm{mgP} / \mathrm{g}$. The $\% \mathrm{SMHC}$ ranged from -41.0 to -29.4 . The enamel wear ranged from $0.15 \mu \mathrm{m}$ to $0.18 \mu \mathrm{m}$. In this in vitro study, the fermented milk beverages did not promote erosion of the dental enamel, but rather only a superficial mineral loss.
\end{abstract}

Descriptors: Fermentation; Probiotics; Dental caries; Dental enamel; Demineralization.

\section{Introduction}

In the last decades, the supply of fermented milk beverages has been growing in the Brazilian market because their consumption has been stimulated due to the alleged benefits of probiotics to the general health. ${ }^{1}$ Probiotics are defined as live microorganisms that, when administered in adequate amounts, are beneficial to the host. ${ }^{1,2}$

Most fermented milk beverages present an acidic $\mathrm{pH}$, and contain sugar and Lactobacillus or Bifidobacterium that produce organic acids. These characteristics can facilitate the adherence of $L$. salivarius to the dental surface and enhance the cariogenicity of $S$. mutans. ${ }^{2}$ In the dental literature, a study by Shibata et al. ${ }^{3}$ (1977) was found on the cariogenic potential of fermented milk. The authors observed the effects of two fer- 
mented milk beverages, "Yakult" and "Calpis", on the development of caries in hamsters and mice. The results indicated that the continuous administration of the beverages promoted caries lesions in the animals. In addition, the induction of erosive lesions could be observed in the enamel of molars. ${ }^{3}$ On the other hand, due to their derivation from milk, fermented milk beverages present calcium and phosphate in their mineral composition, and the simple increment of those minerals in the acidic beverages reduces the erosive effect of those substances. ${ }^{4}$

The influence of ions on the erosive effect of beverages has been the aim of several studies. Calcium and phosphate contents have a protective effect in yogurt, which has a low $\mathrm{pH}(\sim 4)$, and yet it has no erosive potential. ${ }^{5}$ Several properties related to soft drinks have an impact on their erosive potential on teeth after long exposure times, and the addition of calcium and phosphate considerably decreased their erosive potential. ${ }^{6}$ Calcium was found to be effective in reducing the erosive potential of most acidic beverages, while the effect of phosphorus and fluoride, in association with calcium, was less clear.

In view of an increasing consumption of these products, the growing launch of children-oriented advertising campaigns (aiming at an age bracket with greater risk for the development of caries), and the lack of studies concerning the effects of the consumption of fermented milk beverages on the conditions of oral health, the aim of the present in vitro study was to evaluate the erosive capacity of fermented milk beverages and some of their properties that affect the demineralization of dental enamel $(\mathrm{pH}$, buffering capacity, fluoride, calcium and phosphorus concentrations).

\section{Material and Methods Sample selection}

Three batches of 6 different commercial brands of fermented milk beverages (A - Parmalat ${ }^{\circledR}$ Grape, - Parmalat, Carambeí, PR, Brazil; B - Chamyto ${ }^{\circledR}$ Nestlé Brasil Ltda., Araras, SP, Brazil; C - Paulista ${ }^{\circledR}$ - Paulista, Poços de Caldas, MG, Brazil; D - Batavito ${ }^{\circledR}$ - Indústria de Alimentos Batávia S.A, Carambeí, PR, Brazil; E - Yakult ${ }^{\circledR}$ - Yakult S/A Indústria e Comércio, Lorena, SP, Brazil; and F - Vigor ${ }^{\circledR}$ - Vigor,
São Paulo, SP, Brazil) were purchased for analysis of their physicochemical properties.

\section{pH analysis}

The $\mathrm{pH}$ of the products was determined at room temperature using a $\mathrm{pH}$ electrode (2A14-KA Analyzer, São Paulo, SP, Brazil) coupled to a potentiometer (290A, Orion Research Inc., Boston, MA, USA).

\section{Buffering capacity}

Evaluation of the buffering capacity (BC) was accomplished using $5 \mathrm{ml}$ of each product, which were stored in a plastic vial (J10 - Injeplast, São Paulo, $\mathrm{SP}, \mathrm{Brazil}$ ) to determine the initial $\mathrm{pH}$. One $\mathrm{mol} \mathrm{L}^{-1}$ $\mathrm{NaOH}$ (Dinâmica Reagentes Analíticos, São Paulo, SP, Brazil) was added in $25 \mu \mathrm{l}$ increments, until the $\mathrm{pH}$ reached 7.0. ${ }^{8}$

\section{Fluoride analysis}

Fluoride concentrations were determined after overnight hexamethyldisiloxane (HMDS)-facilitated diffusion according to the method described by Taves $^{9}$ (1968) and modified by Whitford ${ }^{10}$ (1996), using a fluoride ion-specific electrode (model 9409, Thermo Electron Corporation, Beverly, MA, USA) and a miniature calomel reference electrode (Accumet \#13-620-79 Fischer Scientific, Pittsburgh, PN, USA), coupled to a potentiometer (290A, Orion Research Inc., Boston, MA, EUA).

\section{Calcium analysis}

Calcium concentration was analyzed by a colorimetric test (Spectrophotometer - Hitachi Lts, Tokyo, Japan) using the cresolphtalein method (Bioclin ${ }^{\circledR}$ Kit, Belo Horizonte, MG, Brazil).

\section{Phosphorus analysis}

Phosphorus concentration was analyzed by the colorimetric test (Spectrophotometer - Hitachi Lts, Tokyo, Japan) according to the method described by Fiske, Subbarow ${ }^{11}$ (1925).

\section{Enamel block preparation and de-remineralization cycles}

Enamel blocks measuring 4 × 4 × 2 mm were obtained from bovine incisor teeth previously stored in 
$2 \%$ formaldehyde solution $(\mathrm{pH} 7.0)$ for one month. They had their surface serially polished (Politriz APL-4, Arotec, Cotia, SP, Brazil) for surface microhardness determination (five indentations in different regions of the blocks, $25 \mathrm{~g}, 5 \mathrm{~s}$, HMV-2000; Shimadzu Corporation, Tokyo, Japan).

Sixty blocks with a mean surface microhardness between 358.6 and 379.8 Knoop Hardness Number (KHN) were divided into 6 groups corresponding to each fermented milk beverage tested. In the first 24 hours, the blocks were immersed in artificial saliva. After that, they were subjected to four cycles of demineralization $(15 \mathrm{ml}$ of the fermented milk for $5 \mathrm{~min}$ ) and remineralization $(15 \mathrm{ml}$ of artificial saliva for $60 \mathrm{~min})$. After each treatment, the specimens were rinsed under deionized water. ${ }^{12}$

In order to maintain reference surfaces for lesion depth determination by profilometry, two layers of nail varnish were applied on half of the surface of each block.

\section{Enamel block analysis}

Enamel mineral loss was determined by surface microhardness $(\mathrm{SMH})^{12}$ and profilometric tests.

The nail varnish over the reference surfaces was carefully cleaned with acetone-soaked (Ace-Rio, Rioquímica, São José do Rio Preto, SP, Brazil) cotton wool. The blocks were dried, and the enamel wear $(R)$ was determined in relation to the reference surface by profilometry, using a rugosimeter (T1000 Tester; Hommelwerke, VS-Schwenningen, Germany). On each specimen, 5 readings were performed by scanning from the reference to the exposed surface.

\section{Statistical analysis}

ANOVA and Tukey's tests were carried out for statistical analysis. The correlations between the percentage of superficial microhardness change (\%SMHC) and the variables such as $\mathrm{pH}$, buffering capacity, and the fluoride, calcium and phosphate contents in the fermented milk beverages were analyzed using Spearman's correlation coefficient. The significance level was set at $5 \%$.

\section{Results}

The samples' $\mathrm{pH}$ ranged from 3.51 to 3.87 (Table 1).

The buffering capacity ranged from 470.8 to 804.2 $\mu \mathrm{L}$ of $1 \mathrm{~mol} \mathrm{~L}^{-1} \mathrm{NaOH}$ (Table 1 ).

The fluoride concentration ranged from 0.027 to $0.958 \mu \mathrm{g} \mathrm{F} / \mathrm{g}$ and the phosphorus concentration ranged from 0.2662 to $0.5043 \mathrm{mg} \mathrm{P} / \mathrm{g}$ (Table 1).

A direct relationship could be observed $(r=0.9308)$ with a significance of 0.0084 between $\mathrm{pH}$ and buffering capacity.

The calcium concentration ranged from 0.4788 to $0.8175 \mathrm{mg} \mathrm{Ca} / \mathrm{g}$ (Table 2).

The \%SMHC ranged from -41.0 to -29.4 . There was significant difference between brands $\mathrm{A}, \mathrm{B}$ and $\mathrm{C}$ (Table 3). Brands $\mathrm{E}$ and $\mathrm{F}$ also showed a statistically significant difference in relation to brands $\mathrm{A}$ and $\mathrm{B}$.

The enamel wear $(\mathrm{R})$ ranged from $0.15 \mu \mathrm{m}$ to $0.18 \mu \mathrm{m}$, but the profilometric test was not capable of showing the presence of significant enamel wear in relation to the reference surface (Table 3).

The \%SMHC (\%SMHCxF: $r=0.339 ; p=0.510$; $\%$ SMHCxCa: $r=0.901 ; p=0.014 ; \%$ SMHCxP:

Table 1 - Mean and standard deviation of the $\mathrm{pH}$, buffering capacity, fluoride concentration and phosphorus concentration of the three batches of the different commercial brands of fermented milk beverages.

\begin{tabular}{c|c|c|c|c}
\hline $\begin{array}{c}\text { Commercial } \\
\text { Brand }\end{array}$ & $\mathrm{pH}$ & Buffering Capacity $(\mu \mathrm{L})$ & $\begin{array}{c}\text { Fluoride concentration } \\
(\mu \mathrm{gF} / \mathrm{g})\end{array}$ & $\begin{array}{c}\text { Phosphorus concentration } \\
(\mathrm{mgP} / \mathrm{g})\end{array}$ \\
\hline A & $3.83 \pm 0.023$ & $470.8 \pm 19.09$ & $0.027 \pm 0.005$ & $0.3286 \pm 0.015$ \\
\hline B & $3.65 \pm 0.006$ & $620.8 \pm 19.09$ & $0.246 \pm 0.023$ & $0.5040 \pm 0.001$ \\
\hline C & $3.52 \pm 0.006$ & $804.2 \pm 19.09$ & $0.196 \pm 0.021$ & $0.4939 \pm 0.003$ \\
\hline D & $3.87 \pm 0.015$ & $570.8 \pm 7.22$ & $0.029 \pm 0.001$ & $0.5043 \pm 0.005$ \\
\hline E & $3.51 \pm 0.026$ & $779.2 \pm 52.04$ & $0.148 \pm 0.051$ & $0.5029 \pm 0.003$ \\
\hline F & $3.54 \pm 0.127$ & $733.3 \pm 40.18$ & $0.958 \pm 0.189$ & $0.2662 \pm 0.001$ \\
\hline
\end{tabular}




\begin{tabular}{|c|c|c|c|c|}
\hline $\begin{array}{r}\text { Table } 2 \text { - Mean and standard } \\
\text { deviation of the calcium } \\
\text { concentration and variation }\end{array}$ & $\begin{array}{c}\text { Commercial } \\
\text { Brand }\end{array}$ & $\begin{array}{l}\text { Calcium concentration (mg } \\
\mathrm{Ca} / \mathrm{g} \text { ) on the label }\end{array}$ & $\begin{array}{l}\text { Calcium concentration } \\
\qquad \begin{array}{c}\text { (mg Ca/g) } \\
\text { in the test }\end{array}\end{array}$ & $\begin{array}{c}\text { Variation Coefficient } \\
(\%)\end{array}$ \\
\hline $\begin{array}{l}\text { coefticient in the three batches of } \\
\text { he different commercial brands of }\end{array}$ & $A$ & 0.8000 & $0.4788 \pm 0.0607$ & -40.15 \\
\hline fermented milk beverages. & B & 0.7375 & $0.8054 \pm 0.0197$ & 9.21 \\
\hline & C & 0.7385 & $0.7295 \pm 0.0278$ & -1.22 \\
\hline & D & 0.8000 & $0.8175 \pm 0.0165$ & 2.18 \\
\hline & $\mathrm{E}$ & 0.8625 & $0.7211 \pm 0.0330$ & -16.39 \\
\hline & $\mathrm{F}$ & 0.8250 & $0.7426 \pm 0.0641$ & -9.99 \\
\hline
\end{tabular}

$\mathrm{r}=0.385 ; \quad \mathrm{p}=0.450 ; \quad \%$ SMHCxpH: $\mathrm{r}=-0.275 ;$ $\mathrm{p}=0.598 ; \%$ SMHCxBC: $\mathrm{r}=0.329 ; \mathrm{p}=0.524)$ and enamel wear $(\mathrm{RxF}: \mathrm{r}=-0.620 ; \mathrm{p}=0.189$; $\mathrm{RxCa}$ : $\mathrm{r}=-0.882 ; \mathrm{p}=0.020 ; \mathrm{RxP}: \mathrm{r}=-0.154 ; \mathrm{p}=0.771$; $\mathrm{RxpH}: \mathrm{r}=0.516 ; \mathrm{p}=0.295 ; \mathrm{RxBC}: \mathrm{r}=-0.664$; $\mathrm{p}=0.151)$ presented correlation only related to the calcium ion.

\section{Discussion}

Several studies have shown the benefits to the general health of the consumption of probiotics, and some have investigated the relationship of this consumption with oral health. ${ }^{1-4}$

The low $\mathrm{pH}$ of fermented milk beverages can be associated with the onset of caries lesions and erosions in the oral cavity, as demonstrated by Shibata et $a .^{3}$ (1977), who evaluated the effect of the continuous administration of the fermented milk beverages "Yakult" and "Calpis" in mice and hamsters. In that study, caries and erosion lesions were observed in the enamel of molars of the animals.

As observed in the present study, all of the fermented milk beverages analyzed presented a low $\mathrm{pH}$ (Table 1), which may contribute to the dissolution of the dental structure according to reports found in the related literature. ${ }^{6,8,13}$ However, this demineralization effect cannot be attributed to foods and beverages taking into account only the $\mathrm{pH}$. Other factors should also be considered, including the physical and chemical properties that affect the adhesion of microorganisms to the dental surface, the stimulation of salivary flow, the buffering capacity of beverages and the presence of fluoride, calcium and phosphate. ${ }^{14-16}$

In the present study, the buffering capacity,
Table 3 - Mean and standard deviation of the \%SMHC and enamel wear of the different commercial brands of fermented milk beverages.

\begin{tabular}{c|c|c}
\hline $\begin{array}{c}\text { Commercial } \\
\text { Brand }\end{array}$ & \%SMHC & Enamel wear $(\mu \mathrm{m})$ \\
\hline A & $-41.0 \pm 3.72^{\mathrm{a}}$ & $0.17 \pm 0.06^{\mathrm{A}}$ \\
\hline B & $-29.4 \pm 4.38^{\mathrm{b}}$ & $0.17 \pm 0.04^{\mathrm{B}}$ \\
\hline C & $-32.2 \pm 5.65^{\mathrm{c}}$ & $0.17 \pm 0.04^{\mathrm{B}}$ \\
\hline$D$ & $-30.2 \pm 2.53^{\mathrm{c}, \mathrm{b}}$ & $0.17 \pm 0.03^{\mathrm{B}}$ \\
\hline E & $-33.3 \pm 2.90^{\mathrm{c}}$ & $0.18 \pm 0.03^{\mathrm{B}, \mathrm{A}}$ \\
\hline F & $-29.7 \pm 4.16^{\mathrm{c}}$ & $0.15 \pm 0.03^{\mathrm{B}}$ \\
\hline
\end{tabular}

and the fluoride, calcium and phosphorus concentrations were also analyzed. The buffering capacity of a substance is related to the resistance to $\mathrm{pH}$ changes. It was observed that the commercial Brand $\mathrm{C}$ presented the largest buffering capacity, requiring $804.2 \mu \mathrm{l}$ of $1 \mathrm{~mol} \mathrm{~L}^{-1} \mathrm{NaOH}$ to reach neutral $\mathrm{pH}$. A direct relationship was observed $(r=0.9308)$ with a significance of 0.0084 between $\mathrm{pH}$ and buffering capacity. This result was corroborated by Edwards et al. ${ }^{8}$ (1999), making it possible to infer that, the smaller the $\mathrm{pH}$ of the beverage, the larger its buffering capacity, thus allowing the acid to stay longer in the oral cavity.

Evaluation of the fluoride concentration is justified due to its important role in the prevention of the formation of caries lesions, a condition that takes place in the presence of an acidic environment, mainly through a topical action. ${ }^{17}$ Although the presence of acid is an important factor in the development of both caries and erosion, these two conditions involve quite different processes. In the 
caries process, fluoride can exert several functions, including the reduction of enamel demineralization and the stimulation of enamel remineralization. ${ }^{13}$ Furthermore, fluoride can accumulate on the dental plaque and then become available for long periods in the oral cavity. ${ }^{18}$ The addition of fluoride to the solution does not alter the $\mathrm{pH}$, although it assumes a protective function, reducing dental erosion. ${ }^{19}$ However, it should be borne in mind that, once the erosion takes place, the presence of fluoride is not capable of promoting remineralization, differently from what occurs during the development of a caries lesion. ${ }^{13}$

Although none of the products indicated the presence of fluoride on their labels, it could be observed in this study that all beverages presented fluoride in their composition. Considering that the optimum fluoride dose to prevent dental fluorosis is 0.05-0.07 mg F/ kg/day, most products (commerical brands A, B, C, D and E) showed a fluoride concentration which was lower than that reference, except for commercial brand F, which presented an average concentration of $0.958 \mu \mathrm{g} \mathrm{F/g}$. Several studies have been conducted to investigate the concentration of fluoride in foods and beverages marketed in Brazil. ${ }^{20-22}$ In a recent study, the presence of fluoride was detected in all types of milk analyzed, and in a brand of ready-to-drink chocolate milk, a concentration of $1.6 \mu \mathrm{g} \mathrm{F} / \mathrm{mL}$ was found. ${ }^{21}$ It can be suggested, based on the relevant studies found in the related literature, that the presence of fluoride adds a protective effect to the solution, but it is important to point out that high fluoride concentrations in children's food and beverages can create a risk for dental fluorosis when a concomitant ingestion of other fluoride sources is considered. ${ }^{13,19}$

Analysis of the calcium and phosphorus contents was accomplished due to their importance in the reduction of the cariogenic and erosive potential when present in the final form of foods and beverages. ${ }^{16,23}$ The addition of calcium to acidic solutions is preferable to that of phosphate because, when the same concentration of both elements was compared, calcium was more efficient in the prevention of erosion. ${ }^{19}$ Furthermore, the addition of calcium did not alter the flavor, differently from phosphate that can produce a metallic taste in the foods. ${ }^{6}$ The addition of calcium and phosphate to acidic solutions changed the onset of the acid attack to human enamel, and these elements proved more efficient in protecting the enamel when their concentrations were increased. ${ }^{24}$ In situ studies have confirmed the protecting effect of calcium and its advantage in reducing the dental erosion provoked by acidic beverages. ${ }^{23}$ All of the fermented milk beverages analyzed in this study presented calcium in their composition, but differences could be observed among the values presented on the labels and those obtained with the test. Most of the beverages (brands B, C, D, E and F) presented a small difference between both values, except for brand $\mathrm{A}$, which presented a variation coefficient (\%) of $-40.15 \%$ (Table 2). Although it has not been informed on the label, all of the fermented milk beverages analyzed presented phosphorus in their composition (Table 1). This information is important to the consumer, since the addition of calcium and phosphorus to acidic beverages reduces their erosive potential. ${ }^{6}$

Moreover, in the present study, no significant correlation was observed between the \%SMHC or enamel wear and the evaluated ion concentrations, except for the calcium ion. Larsen, Nyvad ${ }^{25}$ (1999) stated that the potential of a soft drink to erode dental enamel depends not only on the $\mathrm{pH}$, but also on its buffering capacity. This fact may be influenced by the concentrations of different ions, such as phosphate, fluoride and calcium. ${ }^{12}$ The related literature is contradictory regarding the erosive potential of beverages containing these ions. The effect of fluoride on dental erosion has been studied under various conditions with conflicting results. ${ }^{19,26,27}$ It is possible that increasing the fluoride concentration in acidic drinks could contribute to reduce their erosive potential. However, a review paper showed that fluoride admixtures to acidic solutions in a concentration excluding toxicological side effects seem unable to arrest erosive lesions. ${ }^{28}$ Other studies have shown that beverage modification by addition of calcium is efficient in preventing erosion. ${ }^{29,30}$ Our results corroborate those of previous studies, showing a correlation between both the percentage of superficial microhardness change and enamel wear with 
the calcium concentration in the products.

\section{Conclusions}

Some characteristics which may promote demineralization of the dental enamel, such as low $\mathrm{pH}$ and high buffering capacity, were observed in the products analyzed. On the other hand, the presence of fluoride, calcium and phosphorus ions was ob-

\section{References}

1. Sullivan A, Nord CE. Probiotics and gastrointestinal diseases. J Intern Med. 2005 Jan;257(1):78-92.

2. Matsumoto M, Tsuji M, Sasaki H, Fujita K, Nomura R, Nakamo K et al. Cariogenicity of the probiotic bacterium Lactobacillus salivarius in rats. Caries Res. 2005 Nov-Dec;39(6):47983.

3. Shibata H, Takehara T, Nara Y, Imazato M, Inoue M, Morioka T. Caries-promoting properties of fermented milk beverages containing live or killed lactobacillus. Koku Eisei Gakkai Zasshi. 1977 Jul;27(2):46-58.

4. Hay DI, Pinsent BRW, Schram CJ, Wagg BJ. The protective effect of calcium and phosphate ions against acid erosion of dental enamel and dentine. Br Dent J. 1962;112(3):283-7.

5. Lussi A, Jaeggi T, Jaeggi-Schärer S. Prediction of the erosive potential of some beverages. Caries Res. 1995;29(5):34954.

6. Jensdottir T, Bardow A, Holbrook P. Properties and modification of soft drinks in relation to their erosive potential in vitro. J Dent. 2005 Aug;33(7):569-75.

7. Hara AT, Zero DT. Analysis of the erosive potential of calcium-containing acidic beverages. Eur J Oral Sci. 2008 Feb;116(1):60-5.

8. Edwards M, Creanor SL, Foye RH, Gilmour WH. Buffering capacities of soft drinks: the potential influence on dental erosion. J Oral Rehabil. 1999 Dec;26(12):923-7.

9. Taves DR. Separation of fluoride by rapid diffusion using hexamethyldisiloxane. Talanta. 1968 Sep;15(9):969-74.

10. Whitford GM. The metabolism and toxicity of fluoride. Monogr Oral Sci. 1996;16 Rev 2:1-153.

11. Fiske CH, Subarrow Y. The colorimetric determination of phosphorus. J Biol Chem. 1925;66(1):375-400.

12. de Carvalho Sales-Peres SH, Magalhães AC, de Andrade Moreira Machado MA, Buzalaf MA. Evaluation of the erosive potential of soft drinks. Eur J Dent. 2007 Jan;1(1):10-3.

13. Dawes $\mathrm{C}$. What is the critical $\mathrm{pH}$ and why does a tooth dissolve in acid? J Can Dent Assoc. 2003 Dec;69(11):722-4.

14. Ireland AJ, McGuinness N, Sherriff M. An investigation into the ability of soft drinks to adhere to enamel. Caries Res. $1995 ; 29(6): 470-6$. served, which may reduce the dissolution of dental structure produced by acidic substances. In this in vitro study, the fermented milk beverages did not promote erosion of the dental enamel, but rather only a superficial mineral loss. In situ and clinical studies are recommended to evaluate the erosive potential of fermented milk beverages.

15. Lussi A, Kohler N, Zero D, Schaffner M, Megert B. A comparison of the erosive potential of different beverages in primary and permanent teeth using an in vitro model. Eur J Oral Sci. 2000 Apr;108(2):110-4.

16. Hadwick JL. Enamel caries; a chemico-physical hypothesis; phase one, chemical. Br Dent J. 1950 Jul;89(1):1-6.

17. Clarkson BH, Fejerskov O, Ekstrand J, Burt BA. Rational use of fluorides in caries control. In: Fejerskov O, Ekstrand J, Burt BA, editors. Fluoride in Dentistry. Copenhagen: Munksgaard; 1996. p. 347-57.

18. Rolla G, Ekstrand J. Fluoride in oral fluids and dental plaque. In: Fejerskov O, Ekstrand J, Burt BA, editors. Fluoride in Dentistry. Copenhagen: Munksgaard; 1996. p. 215-29.

19. Hughes JA, West NX, Addy M. The protective effect of fluoride treatments against enamel erosion in vitro. J Oral Rehabil. 2004 Apr;31(1):357-63.

20. Buzalaf MA, de Almeida BS, Cardoso VE, Olympio KP, Furlani $\mathrm{T}$ de $\mathrm{A}$. Total and acid-soluble fluoride content of infant cereals, beverages and biscuits from Brazil. Food Addit Contam. 2004 Mar;21(3):210-5.

21. Buzalaf MA, Pessan JP, Fukushima R, Dias A, Rosa HM. Fluoride content of UHT milks commercially available in Bauru, Brazil. J Appl Oral Sci. 2006 Jan;14(1):38-42.

22. Lodi CS, Ramires I, Pessan JP, Neves LT, Buzalaf MA. Fluoride concentrations in industrialized beverages consumed by children in the city of Bauru, Brazil. J. Appl Oral Sci. 2007 Jun;15(3):209-12.

23. Hughes JA, West NX, Parker DM, Newcombe RG, Addy M. Development and evaluation of a low erosive blackcurrant juice drink in vitro and in situ. 1. Comparison with orange juice. J Dent. 1999 May;27(4):285-9.

24. Grobler SR, Jenkins GN, Kotze D. The effects of the composition and method of drinking of soft drinks on plaque $\mathrm{pH}$. $\mathrm{Br}$ Dent J. 1985 Apr 20;158(8):293-6.

25. Larsen MJ, Nyvad B. Enamel erosion by some soft drinks and orange juices relative to their $\mathrm{pH}$, buffering effect and contents of calcium phosphate. Caries Res. 1999;33(1):81-7.

26. Larsen MJ, Richards A. Fluoride is unable to reduce dental erosion from soft drinks. Caries Res. 2002 Jan-Feb;36(1):7580 . 
27. Meurman JH, Ten Cate JM. Pathogenesis and modifying factors of dental erosion. Eur J Oral Sci. 1996 Apr;104(2(Pt 2)):199-206 .

28. Wiegand A, Attin T. Influence of fluoride on the prevention of erosive lesions - a review. Oral Health Prev Dent. 2003;1(4):245-53.

29. Hughes JA, West NX, Parker DM, Newcombe RG, Addy M. Development and evaluation of a low erosive blackcurrant juice drink. 3. Final drink and concentrate, formulae comparisons in situ and overview of the concept. J Dent. 1999 Jul;27(5):345-50.

30. West NX, Hughes JA, Parker DM, Newcombe RG, Addy M. Development and evaluation of a low erosive blackcurrant juice drink. 2. Comparison with a conventional blackcurrant juice drink and orange juice. J Dent. 1999 Jul;27(5):341-4. 